\title{
Fruit agribusiness waste as an additive in elephant grass silage ${ }^{1}$
}

\section{Resíduos da agroindústria de frutas como aditivos na ensilagem de capim-elefante}

\author{
Jorge Cardoso de Azevedo ${ }^{2 *}$; Saulo Alberto do Carmo Araujo ${ }^{3}$; \\ Norberto Silva Rocha ${ }^{4}$; Arilson Moraes Cardoso ${ }^{5}$; Lílian de Araújo Pantoja ${ }^{3}$; \\ Cristian Faturi ${ }^{6}$; Felipe Nogueira Domingues ${ }^{6}$
}

\begin{abstract}
The purpose of this study was to evaluate the potential use of fruticulture waste as an additive in elephant grass (Pennisetum purpureum) cultivar Napier silage at different densities, defining the effect of fermentative quality, microbiological characteristics and bromatological composition. The experimental design was completely randomized with four replications in a 4 x 3 factorial scheme, comprising a control, banana waste (BW), mango waste (MW), and passion fruit waste (PFW) at three

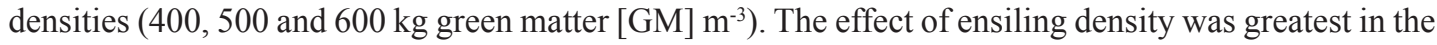
exclusively elephant grass silage, where a compaction of $600 \mathrm{~kg} \mathrm{GM} \mathrm{m}^{-3}$ contributed to improvements in fermentation and microbiological processes. The addition of banana waste to the elephant grass silage promoted improvements only in bromatological composition, raising the dry matter (DM), crude protein (CP), and non-fiber carbohydrate (NFC) content and reducing fiber components (neutral detergent fiber [NDFap] and acid detergent fiber [ADFap] corrected for ash and protein), but the addition of banana waste did not favor the fermentative or microbiological processes. The addition of passion fruit and mango by-products promoted increased DM and favored the fermentative, microbiological, and bromatological silage processes, regardless of density.
\end{abstract}

Key words: Additives. Compaction. Fermentation. Microbial. Pennisetum purpureum.

\section{Resumo}

Objetivamos avaliar o potencial de utilização de resíduos da agroindústria de fruticultura como aditivos na ensilagem de capim-elefante (Pennisetum purpureum) cultivar Napier, sob diferentes massas específicas, determinando seu efeito na qualidade fermentativa, características microbiológicas e composição bromatológica. O delineamento experimental utilizado foi inteiramente casualisado com quatro repetições, em esquema fatorial 4 x 3 , sendo composto por testemunha, resíduo de banana (RB), resíduo de manga (RMg), resíduo de maracujá $(\mathrm{RMj})$ e três massas específicas (400, 500 e $600 \mathrm{~kg}$ matéria verde $[\mathrm{MV}] \mathrm{m}^{-3}$ ). $\mathrm{O}$ efeito da massa específica no silo é mais efetivo na silagem exclusiva de capim-

\footnotetext{
1 Trabalho de Mestrado do Programa de Pós-Graduação em Ciência Animal, Universidade Federal do Pará, UFPA, Castanhal, PA, Brasil, primeiro autor.

2 Zootecnista, Instituto Federal do Maranhão, IFMA, Caxias, MA, Brasil. E-mail: jorgec.azevedo@yahoo.com.br

${ }^{3}$ Profs. Drs., Universidade Federal dos Vales do Jequitinhonha e Mucuri, UFVJM, Unaí, MG, Brasil. E-mail: saulo.araujo@ufvjm. edu.br; 1.pantoja@ict.ufvjm.edu.br

${ }^{4}$ Discente, Programa de Pós-Graduação em Zootecnia, Universidade Federal dos Vales do Jequitinhonha e Mucuri, UFVJM, Diamantina, MG, Brasil. E-mail: nsrocha@gmail.com

${ }^{5}$ Discente, Programa de Pós-Graduação em Ciência Animal, Universidade Federal do Pará, UFPA, Belém, PA, Brasil. E-mail: arilsoncardoso@yahoo.com.br

${ }^{6}$ Profs. Drs., Universidade Federal Rural da Amazônia, UFRA, Belém, PA, Brasil. E-mail: felipend@gmail.com; cfaturi@ig.com.br

* Author for correspondence
} 
elefante, onde a compactação de $600 \mathrm{~kg} \mathrm{MV} \mathrm{m}^{-3}$ contribui para melhorias no processo fermentativo e microbiológico. A adição do resíduo de banana na ensilagem do capim-elefante promoveu melhorias apenas na composição bromotológica, elevando os teores de matéria seca (MS), proteína bruta (PB), carboidratos não fibrosos (CNF) e redução nos componentes fibrosos (fibra em detergente neutro [FDNcp] e fibra em detergente ácido [FDAcp] corrigidos para cinza e proteína), porém não favorece o processo fermentativo e microbiológico. A adição de subprodutos de maracujá e manga promove o aumento da MS e favorece o processo fermentativo, microbiológico e bromatológico da silagem, independente da massa específica.

Palavra-chave: Aditivos. Compactação. Fermentação. Microbiológico. Pennisetum purpureum.

\section{Introduction}

The seasonality of forage production is one of the factors responsible for the low Brazilian livestock productivity rates because sward development is especially accelerated in periods of high rainfall and high temperatures, resulting in a production surplus (OLIVEIRA et al., 2015). Excess forage production is typically underutilized, resulting in delayed grass cutting, compromising both the handling of the grass and the quality of the fodder to be used as livestock feed. In this context, conservation of forage production surplus is an interesting strategy for the use of this material, facilitating the use of preserved material later during the dry season.

While tropical grasses have high nutritional value, they also have low dry matter (DM) content (18-25\%) and low soluble carbohydrate levels (7$8 \%$ ) in their composition along with high buffering capacity (10 to 20 e. mg), which may impair the quality of the final product, the silage (SANTOS et al., 2010).

One alternative for reducing losses during forage preservation and for improving silage quality is to include additives that modulate the fermentation process. One possible alternative among these additives is the use of fruticulture wastes, such as banana, mango, and passion fruit waste.

Data from the Brazilian Institute for Geography and Statistics (IBGE, 2013), the fruit production in Brazil reached 40,180,224 tons, featuring 6,892,622 tons $(17.15 \%)$ of banana, $1,163,000$ tons $(2.89 \%)$ of mango and 838,224 tons (2.08\%) of passion fruit. The total amount of fruit consumed in the domestic market, $47 \%$ is destined for the processing industry, in which losses are generated during the beneficiation process, resulting in tons of agroindustrial waste, which if not properly managed, can lead to serious environmental consequences. According to Nunes et al. (2007), the discarded portion of some fruits may be high, for example, mango (30-50\%), banana $(20 \%)$ and passion fruit $(65-70 \%)$, resulting in a disordered increase of waste production.

According to Lousada Júnior et al. (2006), byproducts derived from the fruticulture industry can contribute both to improving the fermentation pattern of elephant grass silage, when used at appropriate levels, and to raising the nutritional value of the silage.

Research on the use of fruticulture by-products is important because such use enables a suitable destination to be found for wastes with potential environmental effects and may even provide an alternative to improve the conservation quality of ensiled forage derived from tropical grasses. The inclusion of fruit-processing wastes in grass silage can effectively improve the quality of the final product and reduce feeding costs (FERREIRA et al., 2009).

Against this backdrop, the objective of this study was to evaluate the use of banana, mango, and passion fruit waste as additives in elephant grass (Pennisetum purpureum) cultivar Napier silage at different densities. 


\section{Materials and Methods}

The experiment was conducted at the Moura Experimental Farm, belonging to the Federal University of the Valleys of Jequitinhonha and Mucuri (Universidade Federal dos Vales do Jequitinhonha e Mucuri - UFVJM), located in the municipality of Curvelo, Minas Gerais (MG). Laboratory tests to evaluate the silage's fermentative and bromatological characteristics were carried out at the Laboratory of Animal Nutrition, Department of Animal Science (UFVJM), located in the city of Diamantina, MG. Microbiological evaluations were performed in the Laboratory of Bioprocesses and Biotransformation(LabBBio/UFVJM-Diamantina).

The silage was made up of elephant grass (Pennisetum purpureum) cultivar Napier and fruit waste disposed of by local agribusinesses specializing in the production of jams and juices. Wastes from banana, mango, and passion fruit processing were tested as silage additives. In essence, the composition of banana waste is characterized by the presence of peel, that of mango by peel, pit and pulp remains adhering to the discarded material, and that of passion fruit by peel and seeds (Table 1). The wastes were dried in the sun to reach the desired moisture content (10 to $15 \%$ ) before being used. The wastes were then ground in a $2 \mathrm{~mm}$ sieve. The moisture content of the wastes and forage during drying were determined using a microwave oven, according to Lacerda et al. (2009), and subsequently confirmed in a forced air oven at a temperature of $55^{\circ} \mathrm{C}$ for 72 hours (AOAC, 1990).

Table 1. Chemical composition of elephant grass and banana, mango and passion fruit waste, used in experimental silages.

\begin{tabular}{|c|c|c|c|c|}
\hline Variable & Elephant grass & Banana & Mango & Passion fruit \\
\hline $\mathrm{DM}^{1}\left(\mathrm{~g} \mathrm{~kg}^{-1}\right)$ & 184.2 & 888.2 & 902.5 & 903.4 \\
\hline $\mathrm{CP}^{2}\left(\mathrm{~g} \mathrm{~kg}^{-1} \mathrm{DM}\right)$ & 68.5 & 89.2 & 44.5 & 135.2 \\
\hline NDIN/TN ${ }^{3}\left(\mathrm{~g} \mathrm{~kg}^{-1} \mathrm{DM}\right)$ & 148.9 & 391.4 & 181.4 & 254.8 \\
\hline $\mathrm{ADIN} / \mathrm{TN}^{4}\left(\mathrm{~g} \mathrm{~kg}^{-1} \mathrm{DM}\right)$ & 30.0 & 276.7 & 136.4 & 37.7 \\
\hline $\mathrm{EE}^{5}\left(\mathrm{~g} \mathrm{~kg}^{-1} \mathrm{DM}\right)$ & 32.6 & 114.3 & 48.7 & 20.6 \\
\hline $\mathrm{MM}^{6}\left(\mathrm{~g} \mathrm{~kg}^{-1} \mathrm{DM}\right)$ & 67.9 & 154.4 & 31.1 & 111.7 \\
\hline $\mathrm{NDFap}^{7}\left(\mathrm{~g} \mathrm{~kg}^{-1} \mathrm{DM}\right)$ & 681.4 & 524.8 & 456.1 & 405.8 \\
\hline $\mathrm{ADFap}^{8}\left(\mathrm{~g} \mathrm{~kg}^{-1} \mathrm{DM}\right)$ & 455.0 & 347.9 & 302.5 & 275.1 \\
\hline $\mathrm{NFC}^{9}\left(\mathrm{~g} \mathrm{~kg}^{-1} \mathrm{DM}\right)$ & 149.6 & 117.3 & 419.7 & 343.6 \\
\hline $\mathrm{TC}^{10}\left(\mathrm{~g} \mathrm{~kg}^{-1} \mathrm{DM}\right)$ & 831.0 & 642.1 & 875.8 & 732.6 \\
\hline $\operatorname{HEM}^{11}\left(\mathrm{~g} \mathrm{~kg}^{-1} \mathrm{DM}\right)$ & 226.5 & 176.2 & 153.6 & 130.8 \\
\hline $\operatorname{Lig}^{12}(\% \mathrm{DM})$ & 124.1 & 81.2 & 66.6 & 89.5 \\
\hline
\end{tabular}

${ }^{1} \mathrm{DM}$ - dry matter; ${ }^{2} \mathrm{CP}$ - crude protein; ${ }^{3} \mathrm{NDIN} / \mathrm{TN}$ - neutral detergent insoluble nitrogen as a percentage of total nitrogen; ${ }^{4} \mathrm{ADIN} /$ $\mathrm{TN}$ - acid detergent insoluble nitrogen as a percentage of total nitrogen; ${ }^{5} \mathrm{EE}$ - ether extract; ${ }^{6} \mathrm{MM}-$ mineral matter; ${ }^{7} \mathrm{NDFap}-$ neutral detergent fiber corrected for ash and protein; ${ }^{8} \mathrm{ADFap}$ - acid detergent fiber corrected for ash and protein; ${ }^{9} \mathrm{NFC}-$ non-fiber carbohydrate; ${ }^{10} \mathrm{TC}$ - total carbohydrates; ${ }^{11} \mathrm{HEM}$ - hemicellulose; ${ }^{12} \mathrm{LIG}$ - lignin.

The experimental silos were constructed of PVC (polyvinyl chloride) tubes, measuring 60 and 15 $\mathrm{cm}$ in height and diameter, respectively, equipped with bottom and top covers as well a rubber seal on the side and a Bunsen valve. A 12-cm layer of sand, corresponding to $20 \%$ of the total height of the experimental silo, and a protective screen were used for effluent drainage during fermentation. Altogether, 48 experimental silos were constructed.

The elephant grass was cut on 20 March 2014 at a mean height of $1.6 \mathrm{~m}$ above the soil and cut to the ground. After the grass was chopped $(2-\mathrm{cm})$ and homogenized, the dry matter content of the elephant grass was determined (LACERDA et al., 2009). To 
calculate the amount of additive to be included in the silage, a final DM content of $30 \%$ was used, a value recommended by McDonald et al. (1991) to achieve good fermentation. A total of $16.45 \%$ banana waste, $16.12 \%$ mango waste, and $16.10 \%$ passion fruit waste were used to achieve this DM content in the silage. The amount of mass ensiled was determined by the volume of the experimental silos, which were equal in dimension, and the desired density of each treatment.

After 240 days, the experimental silos were opened and analyzed for fermentation and for microbiological and bromatological quality.

Juice was extracted from part of the fresh silage removed from the silo after homogenization with the aid of a hydraulic press. The sample was divided for $(\mathrm{pH})$ determination, following the procedures described by Cherney and Cherney (2003), and for ammonia nitrogen $\left(\mathrm{N}-\mathrm{NH}_{3}\right)$ content determination, for which the material was preserved in $0.036 \mathrm{~N}$ sulfuric acid and frozen for later determination by distillation with magnesium oxide (AOAC, 1990).

Sample preparation for microbiological analysis began with a dilution, where $25 \mathrm{~g}$ of silage was weighed and $225 \mathrm{ml}$ of $0.1 \%$ sterile peptone bacteriological water was added, which was sterilized $\left(121^{\circ} \mathrm{C}\right.$ for 15 minutes) and vortexed for 20 minutes. From the diluted extracts $\left(10^{-1}\right.$ to $\left.10^{-6}\right)$, sowings were carried out for evaluation of lactic acid bacteria (LAB), yeasts, and filamentous fungi (molds). For total microorganism counts, $0.1 \mathrm{ml}$ of each dilution was partitioned in triplicate and spread with a Drigalski spatula on Lactobacilli MRS (de Man Rogosa Sharpe) agar medium (Difco), adding nystatin $(0.4 \%)$ for $\mathrm{LAB}$ counts. The Petri dishes were incubated at $30^{\circ} \mathrm{C}$ for 96 hours (ÁVILA et al., 2008). Potato dextrose agar (PDA) was used for filamentous fungi count, with the addition of chloramphenicol $\left(100 \mathrm{mg} / \mathrm{l}^{-1}\right)$. The samples were incubated at $28^{\circ} \mathrm{C}$ for 120 hours, and the $\mathrm{pH}$ of the culture medium was adjusted to 3.5 (CHAVES et al., 2011). Yeast-extract-peptone-glucose (YEPG) medium was used for the yeast count $(0.3 \%$ yeast extract, $0.3 \%$ malt extract, $0.5 \%$ peptone, $1.0 \%$ glucose, $2.0 \%$ agar per liter, containing $100 \mathrm{mg} / \mathrm{l}^{-1}$ chloramphenicol), and the samples were incubated at $28^{\circ} \mathrm{C}$ for 72 hours, adjusting the $\mathrm{pH}$ to 3.5 (ÁVILA et al., 2008). Dishes that had between 30 and 300 colony forming units (CFUs) per dish were counted. The number of microorganisms present were counted as a CFU and expressed as a logarithm to base 10 .

The bromatological quality of the elephant grass, wastes (prior to ensiling), and the final product after the opening of experimental silos was evaluated. Samples pre-dried in a forced air oven at $55^{\circ} \mathrm{C}$ for 72 hours were ground in a Wiley mill with a $1 \mathrm{~mm}$ sieve and again dried in an oven $\left(105^{\circ} \mathrm{C}\right.$ for 16 hours $)$ for analysis of the DM content. Crude protein (CP), mineral matter (MM), and ether extract (EE) were analyzed according to AOAC (1990). The levels of neutral detergent fiber corrected for ash and protein (NDFap) and acid detergent fiber corrected for ash and protein (ADFap) were analyzed using $\alpha$-amylase following the sequential method described by Van Soest et al. (1991). The hemicellulose (HEM) content was calculated as the difference between NDF and ADF. Neutral detergent insoluble nitrogen (NDIN) and acid detergent insoluble nitrogen (ADIN) levels were determined according to Licitra et al. (1996). Concentrations of total carbohydrates (TC) and non-fiber carbohydrates (NFC) were obtained according to Sniffen et al. (1992), using the expressions $\mathrm{TC}=100-(\% \mathrm{CP}+\% \mathrm{EE}+\% \mathrm{MM})$ and $\mathrm{NFC}=100-(\% \mathrm{CP}+\% \mathrm{EE}+\% \mathrm{NDF} a \mathrm{p}+\mathrm{MM})$.

The experimental design was completely randomized in a $4 \times 3$ factorial scheme, with a control (without waste) and 3 industrial wastes (banana, mango, and passion fruit) treatments at three densities $(400,500$, and $600 \mathrm{~kg}$ green matter $[\mathrm{GM}] \mathrm{m}^{-3}$ ) and with 4 replicates. The treatments were analyzed using the R software (R DEVELOPMENT TEAM, 2006), considering a 5\% level of probability $(\mathrm{P}<0.05)$ to be statistically significant. Tukey's test at the 5\% significance level was used to compare the means of each treatment when the treatment influenced the dependent variable. 
The statistical model used for analysis was:

$$
Y_{i j}=\mu+W_{i}+D_{j}+(W * D) i j+e_{i j}
$$

where $\mathrm{Y}_{\mathrm{ijk} \mathrm{k}}$ is the value of the response variable in question;

$=$ overall variable mean;

$\mathrm{Wi}=$ fixed effect of the $\mathrm{i}$-th waste, with $\mathrm{i}=$ control, banana waste, mango waste, and passion fruit waste;

$\mathrm{Dj}=$ fixed effect of the $\mathrm{j}$-th density, with $\mathrm{j}=400$, 500, and $600\left(\mathrm{~kg} \mathrm{GM} \mathrm{m}^{-3}\right)$;

$(\mathrm{W} * \mathrm{D}) \mathrm{ij}=$ fixed effect of the interaction of the $\mathrm{i}$-th additive and $\mathrm{j}$-th density; and

$\mathrm{e}_{\mathrm{ij}}=$ experimental error of the observation.

\section{Results and Discussion}

The additive $\mathrm{x}$ density interaction was observed for the $\mathrm{DM}$ values $(\mathrm{P}<0.05)$. The addition of banana, passion fruit, and mango waste to the elephant grass silage led to increased silage DM, regardless of density $(\mathrm{P}<0.05)$, demonstrating the efficacy of the fruit wastes as moisture-absorbing additives (Table 2). Although the $300 \mathrm{~g} \mathrm{~kg}^{-1} \mathrm{DM}$ desired in the experiment and recommended by McDonald et al. (1991) was not achieved, the silages with additives had values very close to the ideal needed for lactic fermentation. The benefits arising from the effect of increasing silage DM content favor lactic fermentation and inhibit Clostridium bacteria. As DM increases, water activity progressively decreases, favoring fermentation even when the content is not considered ideal (JOBIM et al., 2007). However, DM is only indicative of, and not equivalent to, silage quality.

Table 2. Breakdown of additive $\mathrm{x}$ density interaction for the variables $\mathrm{DM}, \mathrm{pH}$ and $\mathrm{N}-\mathrm{NH}_{3}$ of elephant grass silage treated whith banana, mango and passion fruit waste.

\begin{tabular}{|c|c|c|c|c|}
\hline \multirow{2}{*}{ Additive } & \multicolumn{3}{|c|}{ Density kg GM m ${ }^{-3}$} & \multirow{2}{*}{ Mean } \\
\hline & 400 & 500 & 600 & \\
\hline \multicolumn{5}{|c|}{ Dry matter $\left(\mathrm{g} \mathrm{kg}^{-1} \mathrm{DM}\right)$} \\
\hline Control & $188.8 \mathrm{bB}$ & $215.6 \mathrm{cA}$ & $202.8 \mathrm{cAB}$ & 202.4 \\
\hline Banana waste & $298.8 \mathrm{aA}$ & $313.3 \mathrm{aA}$ & $281.0 \mathrm{bB}$ & 297.7 \\
\hline Mango waste & $292.1 \mathrm{a}$ & $295.0 \mathrm{~b}$ & $306.3 \mathrm{a}$ & 297.8 \\
\hline Passion fruit waste & $288.6 \mathrm{a}$ & $291.4 \mathrm{~b}$ & $291.4 \mathrm{~b}$ & 290.5 \\
\hline Mean & 267.1 & 278.8 & 270.4 & $\mathrm{CV}^{1} 3.32$ \\
\hline \multicolumn{5}{|c|}{$\mathrm{pH}$} \\
\hline Control & $5.21 \mathrm{aA}$ & $4.65 \mathrm{bB}$ & $3.72 \mathrm{bC}$ & 4.53 \\
\hline Banana waste & $5.32 \mathrm{a}$ & $5.37 \mathrm{a}$ & $5.33 \mathrm{a}$ & 5.34 \\
\hline Mango waste & $3.41 \mathrm{c}$ & $3.48 \mathrm{~d}$ & $3.41 \mathrm{c}$ & 3.43 \\
\hline Passion fruit waste & $4.08 \mathrm{bA}$ & $3.86 \mathrm{cB}$ & $3.79 \mathrm{bB}$ & 3.91 \\
\hline Mean & 4.51 & 4.34 & 4.07 & $\mathrm{CV}^{1} 2.85$ \\
\hline \multicolumn{5}{|c|}{ Ammonia nitrogen expressed as \% total nitrogen $\left(\mathrm{g} \mathrm{kg}^{-1} \mathrm{~N}^{\left.-\mathrm{NH}_{3} / \mathrm{TN}\right)}\right.$} \\
\hline Control & $115.6 \mathrm{bA}$ & $63.9 \mathrm{bB}$ & $49.5 \mathrm{cC}$ & 76.3 \\
\hline Banana waste & $138.5 \mathrm{aA}$ & $123.5 \mathrm{aB}$ & $107.2 \mathrm{aC}$ & 123.0 \\
\hline Mango waste & $21.9 \mathrm{dA}$ & $15.8 \mathrm{cB}$ & $13.5 \mathrm{~dB}$ & 17.1 \\
\hline Passion fruit waste & $97.8 \mathrm{cA}$ & $59.3 \mathrm{bC}$ & $73.2 \mathrm{bB}$ & 76.8 \\
\hline Mean & 93.4 & 65.6 & 60.8 & $\mathrm{CV}^{1} 4.05$ \\
\hline
\end{tabular}


The $\mathrm{pH}$ was significantly affected $(\mathrm{P}<0.05)$ by the additive $\mathrm{x}$ density interaction (Table 2). The lower $\mathrm{pH}$ found in the silages containing the mango and passion fruit waste, compared to the other treatments, may be associated with the higher NFC content in mango and passion fruit waste in relation to banana waste and forage (Table 1).

The $\mathrm{pH}$ values were correlated with the NFC concentrations of the waste and forage to be ensiled, contributing to the production of organic acids, a prerequisite for obtaining good silage. According to Cândido et al. (2007), NFCs serve as substrates for the development of LAB, acting on the fermentation process and improving the nutritional value of the silage.

Although the silage containing passion fruit waste had a higher $\mathrm{pH}$ value than the silage containing mango waste, regardless of density, all of its $\mathrm{pH}$ values were below 4.2, characterizing it as good quality silage and indicating good fermentation (MCDONALD et al., 1991).

The control silage only exhibited $\mathrm{pH}$ values within the range considered ideal (4.2) at a density of $600 \mathrm{~kg} \mathrm{GM} \mathrm{m}^{-3}$, and the values of the control and passion fruit waste treatments were not significantly different. The rapid anaerobic condition established within the control silage at a density of $600 \mathrm{~kg} \mathrm{GM}$ $\mathrm{m}^{-3}$ probably contributed to the reduction in $\mathrm{pH}$, demonstrating that the effect of compaction on $\mathrm{pH}$ is stronger in silage without additives.

For all the densities, the treatment containing banana waste had the highest $\mathrm{pH}$, and for a density of $400 \mathrm{~kg} \mathrm{GM} \mathrm{m}^{-3}$, the control and banana waste silage did not differ.

The additive $\mathrm{x}$ density interaction had a significant effect $(\mathrm{P}<0.05)$ on the production of $\mathrm{N}-\mathrm{NH}_{3}$. For each additive, the $\mathrm{N}-\mathrm{NH}_{3}$ content decreased as the additive density increased, the result of better fermentation (Table 2).
The treatment containing mango waste had the lowest $\mathrm{N}-\mathrm{NH}_{3}$ content. The control silage was more strongly affected by the density factor, with a sharp reduction in $\mathrm{N}-\mathrm{NH}_{3}$ content noted for a compaction of $600 \mathrm{~kg} \mathrm{GM} \mathrm{m}^{-3}$. The results demonstrate that for silages with a lower $\mathrm{pH}, \mathrm{N}-\mathrm{NH}_{3}$ was also lower, indicating that these silages had better fermentation conditions.

One of the most important changes that occur in the silage fermentation process in terms of defining fermentation quality is an increase in $\mathrm{N}_{-} \mathrm{NH}_{3}$ content in relation to total nitrogen as a result of the action of silage spoilage microorganisms. Acidic conditions $(\mathrm{pH}<4.2)$, reduction in water activity (addition of moisture-absorbing additives), and the supply of soluble carbohydrates are the main factors that lead to decreased $\mathrm{N}^{-\mathrm{NH}_{3}}$ production (MCDONALD et al., 1991).

These results corroborate those obtained by Sá et al. (2007), who studied elephant grass silages with different amounts of mango processing byproduct and found that $\mathrm{N}-\mathrm{NH}_{3}$ levels decreased by 0.47 percentage points for every $1 \%$ added and that DM content increased by 0.50 percentage points for every additional $1 \%$ of by-product.

The population of lactic acid bacteria was influenced by the additive $\mathrm{x}$ density interaction $(\mathrm{P}<0.05)$. The treatments followed a similar pattern, with increased density likely reducing oxygen concentration, improving fermentation conditions for the growth of LAB, and causing an increase in their population (Table 3). An anaerobic environment is essential in preventing the growth of most of the spoilage microorganisms that compete with LAB (SANTOS; ZANINE, 2006). 
Table 3. Mean lactic acid bacteria and yeast development values for the additive $\mathrm{x}$ density interaction of elephant grass silage treated whith banana, mango and passion fruit waste.

\begin{tabular}{|c|c|c|c|c|}
\hline \multirow{2}{*}{ Additive } & \multicolumn{3}{|c|}{ Density kg GM m-3 } & \multirow{2}{*}{ Mean } \\
\hline & 400 & 500 & 600 & \\
\hline \multicolumn{5}{|c|}{ LAB (log cfu g ${ }^{-1}$ of silage) } \\
\hline Control & $5.35 \mathrm{dC}$ & $6.62 \mathrm{bB}$ & $7.23 \mathrm{bcA}$ & 6.23 \\
\hline Banana waste & $5.88 \mathrm{cC}$ & $6.40 \mathrm{bB}$ & $7.00 \mathrm{cA}$ & 6.45 \\
\hline Mango waste & $6.59 \mathrm{bB}$ & $7.41 \mathrm{aA}$ & $7.49 \mathrm{abA}$ & 6.64 \\
\hline Passion fruit waste & $7.11 \mathrm{aB}$ & $7.32 \mathrm{aB}$ & $7.73 \mathrm{aA}$ & 6.67 \\
\hline Mean & 6.23 & 6.94 & 7.36 & $\mathrm{CV}^{1} 2.12$ \\
\hline \multicolumn{5}{|c|}{ Yeast (log cfu g ${ }^{-1}$ silage $)$} \\
\hline Control & $4.59 \mathrm{aA}$ & $4.16 \mathrm{aB}$ & $3.35 \mathrm{C}$ & 4.03 \\
\hline Banana waste & $3.71 \mathrm{bA}$ & $3.70 \mathrm{bA}$ & $3.43 \mathrm{~B}$ & 3.61 \\
\hline Mango waste & $3.63 \mathrm{~b}$ & $3.42 \mathrm{c}$ & 3.55 & 3.53 \\
\hline Passion fruit waste & $3.67 \mathrm{bA}$ & $3.51 \mathrm{bcAB}$ & $3.32 \mathrm{~B}$ & 3.50 \\
\hline Mean & 3.90 & 3.70 & 3.41 & $\mathrm{CV}^{1} 3.88$ \\
\hline
\end{tabular}

Good preservation and stabilization of the silo culture results from the combination of an anaerobic environment and LAB growth. An anaerobic environment is one of the factors responsible for $\mathrm{LAB}$ growth and is the only way to prevent the growth of the yeasts, filamentous fungi, and aerobic bacteria responsible for silage deterioration (MUCK, 2010).

The treatments containing mango and passion fruit waste had larger LAB populations than the treatment with addition of banana waste for all the studied densities. The greater NFC content derived from the mango and passion fruit waste was probably essential in increasing the LAB population.

The exclusively grass silage had a smaller LAB population than the silage with passion fruit waste but did not differ from the silage with added mango waste at a density of $600 \mathrm{~kg} \mathrm{GM} \mathrm{m}^{-3}$, but for the other compactions, the grass silage had a smaller LAB population. The greatest growth of LAB in the control treatment at the greatest density $(600 \mathrm{~kg}$ $\mathrm{GM} \mathrm{m}^{-3}$ ) occurred because small yeast populations, lower $\mathrm{N}_{-} \mathrm{NH}_{3}$ content, and low $\mathrm{pH}$, conditions favorable for a good fermentation, were all found at this point.
The additive $\mathrm{x}$ density interaction had an effect $(\mathrm{P}<0.05)$ on the yeast population. Analyzing the effect of the additive for each waste, the density variation did not influence the treatment containing mango waste. The remaining treatments exhibited a decrease in yeast population as density increased (Table 3).

For the $600 \mathrm{~kg} \mathrm{GM} \mathrm{m}^{-3}$ density, the yeast population did not differ among treatments. The variation in density influenced the yeast population only at the lower compactions, where treatments with fruit waste had smaller yeast populations, demonstrating that at lower compactions, additives help control yeast growth.

The filamentous fungi population was influenced by the factors additive and density $(\mathrm{P}<0.05)$, but the interaction was not significant $(\mathrm{P}>0.05)$. There was a difference only between the densities of 400 and $600 \mathrm{~kg} \mathrm{GM} \mathrm{m}^{-3}$, probably because the density of 400 $\mathrm{kg} \mathrm{GM} \mathrm{m}^{-3}$ had an increased oxygen concentration compared to the $600 \mathrm{~kg} \mathrm{GM} \mathrm{m}^{-3}$ density, and this difference, added to the higher $\mathrm{pH}$ at the lower density (Table 2), created a favorable environment for the development of fungi (Table 4). 
Table 4. Mean filamentous fungi population values of elephant grass silage treated whith banana, mango and passion fruit waste.

\begin{tabular}{lccccccc}
\hline & \multicolumn{4}{c}{ Additive } & \multicolumn{2}{c}{ Effect } \\
\hline & Control & $\mathrm{BW}^{1}$ & $\mathrm{MW}^{2}$ & $\mathrm{PFW}^{3}$ & $\mathrm{~A}^{6}$ & $\mathrm{CV}^{4}$ & $\mathrm{AxD}^{7}$ \\
\hline Filamentous fungi & \\
\hline & $3.86 \mathrm{a}$ & $3.40 \mathrm{ab}$ & $3.27 \mathrm{~b}$ & $2.97 \mathrm{~b}$ & $*$ & 10.97 & $\mathrm{NS}^{8}$ \\
\hline & Density kg GM m & \\
\hline & 400 & 500 & & & & & \\
Filamentous fungi $^{5}$ & $3.53 \mathrm{a}$ & $3.53 \mathrm{a}$ & 200 & $3.09 \mathrm{~b}$ & $*$ & 7.36 & $\mathrm{NS}^{8}$ \\
\hline
\end{tabular}

Means followed by the same letter do not differ according to Tukey's test (P $>0.05)$; ${ }^{1} \mathrm{BW}$ : banana waste; ${ }^{2} \mathrm{MW}$ : mango waste; ${ }^{3} \mathrm{PFW}$ : passion fruit waste; ${ }^{4} \mathrm{CV}$ : coefficient of variation (\%); ${ }^{5}$ Filamentous fungi (log $\mathrm{CFU} / \mathrm{g}$ forage); ${ }^{8} \mathrm{~A}$ : additive factor; D: density factor; ${ }^{7} \mathrm{AxD}$ : additive $\mathrm{x}$ density interaction; ${ }^{8} \mathrm{NS}$ : not significant.

According to Ávila et al. (2009), filamentous fungi grow better under aerobic conditions and at a higher $\mathrm{pH}$ (5.0 to 6.0). The silages containing mango and passion fruit waste had a lower fungal population than the control silage and did not differ in relation to the treatment with banana waste.
The TC and NFC parameters were affected by the additive $\mathrm{x}$ density interaction $(\mathrm{P}<0.05)$. The NFC and TC levels followed the trend of the original waste and forage values (Table 5).

Table 5. Mean total carbohydrate and non-fiber carbohydrate values for the additive $x$ density interaction of elephant grass silage treated whith banana, mango and passion fruit waste.

\begin{tabular}{lcccc}
\hline \multirow{2}{*}{ Additive } & \multicolumn{3}{c}{ Density kg GM m${ }^{-3}$} & \multirow{2}{*}{ Mean } \\
\cline { 2 - 4 } & \multicolumn{3}{c}{500} & 600 \\
\hline Control & $825.2 \mathrm{a}$ & $821.7 \mathrm{a}$ & $819.8 \mathrm{a}$ & 822.2 \\
Banana waste & $699.1 \mathrm{cB}$ & $711.7 \mathrm{~dB}$ & $730.0 \mathrm{cA}$ & 713.6 \\
Mango waste & $836.6 \mathrm{aA}$ & $804.8 \mathrm{bB}$ & $794.4 \mathrm{bB}$ & 811.9 \\
Passion fruit waste & $781.8 \mathrm{~b}$ & $774.6 \mathrm{c}$ & $779.1 \mathrm{~b}$ & 778.5 \\
\hline Mean & 785.7 & 778.2 & 780.8 & $\mathrm{CV}^{1} 1.12$ \\
\hline \multicolumn{4}{c}{ Non-fiber carbohydrates $\left(\mathrm{g} \mathrm{kg}^{-1} \mathrm{DM}\right)$} \\
\hline Control & $115.5 \mathrm{c}$ & $107.8 \mathrm{~b}$ & $123.8 \mathrm{~b}$ & 115.7 \\
Banana waste & $88.6 \mathrm{cB}$ & $115.2 \mathrm{bAB}$ & $139.9 \mathrm{bA}$ & 114.6 \\
Mango waste & $264.3 \mathrm{aA}$ & $218.0 \mathrm{aB}$ & $198.0 \mathrm{aB}$ & 226.7 \\
Passion fruit waste & $192.3 \mathrm{~b}$ & $187.9 \mathrm{a}$ & $188.9 \mathrm{a}$ & 189.7 \\
\hline Mean & 165.1 & 157.2 & 162.7 & $\mathrm{CV}^{1} 13.88$ \\
\hline
\end{tabular}

Means followed by the same lowercase letter in the column and uppercase letter in the row do not differ according to Tukey's test $(\mathrm{P}>0.05) ;{ }^{1} \mathrm{CV}$ : coefficient of variation of the additive $\mathrm{x}$ compaction interaction $(\%)$.

There was a significant effect on the NDFap, ADFap, and HEM parameters only for the additive factor $(\mathrm{P}<0.05)$, with no effect observed for different densities and for the additive $\mathrm{x}$ density interaction $(\mathrm{P}>0.05)$.

A reduction $(\mathrm{P}<0.05)$ was observed in the NDFap, ADFap, and HEM levels with the addition of waste (Table 6), with no difference among the treatments with waste for the NDFap and HEM parameters, which differed only from the control treatment. The treatment containing banana waste had a higher ADFap content than the other waste treatments, and these other treatments did not differ from each other. This finding resulted from the higher ADFap content in banana waste (Table 1). 
Table 6. Mean hemicellulose, NDFap, and ADFap values of elephant grass silage treated whith banana, mango and passion fruit waste.

\begin{tabular}{lccccccc}
\hline \multicolumn{7}{c}{ Additive } & \multicolumn{3}{c}{ Effect } \\
\hline & Control & $\mathrm{BW}^{1}$ & $\mathrm{MW}^{2}$ & $\mathrm{PFW}^{3}$ & $\mathrm{~A}^{9}$ & $\mathrm{CV}^{4}$ & $\mathrm{AxD}^{8}$ \\
\hline HEM $^{6}$ & $255.6 \mathrm{a}$ & $198.8 \mathrm{~b}$ & $201.7 \mathrm{~b}$ & $201.9 \mathrm{~b}$ & $*$ & 12.79 & $\mathrm{NS}^{12}$ \\
NDFap $^{7}$ & $706.5 \mathrm{a}$ & $599.0 \mathrm{~b}$ & $584.5 \mathrm{~b}$ & $588.8 \mathrm{~b}$ & $*$ & 9.39 & $\mathrm{NS}^{12}$ \\
ADFap $^{8}$ & $451.0 \mathrm{a}$ & $400.2 \mathrm{~b}$ & $382.8 \mathrm{c}$ & $387.0 \mathrm{c}$ & $*$ & 7.75 & $\mathrm{NS}^{12}$ \\
\hline \multicolumn{7}{c}{ Density kg GM m} \\
\hline
\end{tabular}

Means followed by the same letter do not differ according to Tukey's test (P > 0.05); ${ }^{1} \mathrm{BW}$ : banana waste; ${ }^{2} \mathrm{MW}$ : mango waste; ${ }^{3} \mathrm{PFW}$ : passion fruit waste; ${ }^{4} \mathrm{CV}$ : coefficient of variation of additive (\%); ${ }^{5} \mathrm{CV}$ : coefficient of variation of density $(\%)$; ${ }^{6} \mathrm{HEM}$ : hemicellulose $\left(\mathrm{g} \mathrm{kg}^{-1} \mathrm{DM}\right) ;{ }^{7} \mathrm{NDFap}$ : neutral detergent fiber free of ash and protein $\left(\mathrm{g} \mathrm{kg}^{-1} \mathrm{DM}\right) ;{ }^{8} \mathrm{ADF} a p$ : acid detergent fiber free of ash and protein ( $\left.\mathrm{g} \mathrm{kg}^{-1} \mathrm{DM}\right) ;{ }^{9} \mathrm{~A}$ : additive factor; ${ }^{10} \mathrm{D}$ : density factor; ${ }^{11} \mathrm{AxD}$ : additive $\mathrm{x}$ density interaction; ${ }^{12} \mathrm{NS}$ : not significant.

The reduction in the NDFap, ADFap, and HEM levels in the treatments with fruit waste compared to exclusively grass silage was expected because the wastes have a lower NDFap, ADFap, and HEM content than the grass (Table 1).

According to Ribeiro et al. (2014), NDF content is an important parameter in defining forage quality and is one of the factors that most limits feed consumption because of the physical rumenfilling effect. Dry matter intake is limited when NDF content varies between 600 and $500 \mathrm{~g} \mathrm{~kg}^{-1}$ (CARVALHO et al., 2006), a situation found in all the treatments. However, the exclusively elephant grass silage had a mean NDFap content of 706.5 $\mathrm{g} \mathrm{kg}^{-1}$, which was higher than the other treatments (Table 6).

Cruz et al. (2010) studied the effect of adding dried passion fruit peel at four levels of inclusion $(0,10,20$, and $30 \%)$ to silage and found that the addition of the by-product had a decreasing linear effect on NDF and ADF content. The treatment with $0 \%$ inclusion had an NDF and ADF content of 765 and $515 \mathrm{~g} \mathrm{~kg}^{-1}$, respectively, whereas the treatment with $30 \%$ inclusion of the by-product had a content of 589 and $493 \mathrm{~g} \mathrm{~kg}^{-1}$, respectively.
Sá et al. (2007) studied the effect of adding mango processing by-product to elephant grass silage at five different levels $(0,5,10,15$, and 20\%) and found that the inclusion of this additive in the silage promoted a reduction in NDF and ADF silage content. They obtained a reduction of 0.51 and 0.27 percentage units in NDF and ADF, respectively, for every $1 \%$ of mango by-product added.

The additive $\mathrm{x}$ density interaction had a significant effect $(\mathrm{P}<0.05)$ on the $\mathrm{CP}$ parameter (Table 7). Exploring this interaction by analyzing the effect of density for each additive, smaller CP values were found for the control silage at densities of 400 and $500 \mathrm{~kg} \mathrm{GM} \mathrm{m}^{-3}$ compared to a density of $600 \mathrm{~kg} \mathrm{GM} \mathrm{m}^{-3}$. This finding resulted from unwanted fermentations occurring with greater intensity at the smaller densities, as can be evidenced by the larger yeast populations, smaller LAB populations, and increased $\mathrm{pH}$ and $\mathrm{N}-\mathrm{NH}_{3}$ levels.

Increased $\mathrm{CP}$ consumption and its conversion into $\mathrm{N}-\mathrm{NH}_{3}$ at lower densities coupled with favorable conditions, such as a higher $\mathrm{pH}$ value, lower DM content, and higher oxygen concentration, indicate the presence of bacteria of the genus Clostridium at the lower compactions. 
Table 7. Mean crude protein and ether extract values for the additive $x$ density interaction of elephant grass silage treated whith banana, mango and passion fruit waste.

\begin{tabular}{|c|c|c|c|c|}
\hline \multirow{2}{*}{ Additive } & \multicolumn{3}{|c|}{ Density kg GM m${ }^{-3}$} & \multirow{2}{*}{ Mean } \\
\hline & 400 & 500 & 600 & \\
\hline \multicolumn{5}{|c|}{ Crude protein $\left(\mathrm{g} \mathrm{kg}^{-1} \mathrm{DM}\right)$} \\
\hline Control & $53.9 \mathrm{cB}$ & $54.0 \mathrm{cB}$ & $66.6 \mathrm{bA}$ & 58.2 \\
\hline Banana waste & $70.8 \mathrm{~b}$ & $75.8 \mathrm{~b}$ & $69.2 b$ & 71.9 \\
\hline Mango waste & $55.9 \mathrm{cB}$ & $70.3 \mathrm{bA}$ & $71.9 \mathrm{bA}$ & 66.0 \\
\hline Passion fruit waste & $96.0 \mathrm{a}$ & $100.5 \mathrm{a}$ & $96.7 \mathrm{a}$ & 97.7 \\
\hline Mean & 69.2 & 75.2 & 76.1 & $\mathrm{CV}^{1} 5.29$ \\
\hline \multicolumn{5}{|c|}{ Ether extract $\left(\mathrm{g} \mathrm{kg}^{-1} \mathrm{DM}\right)$} \\
\hline Control & $29.2 \mathrm{cAB}$ & $24.6 \mathrm{~dB}$ & $33.0 \mathrm{bA}$ & 28.9 \\
\hline Banana waste & $76.2 \mathrm{aB}$ & $83.8 \mathrm{aA}$ & $71.5 \mathrm{aB}$ & 77.2 \\
\hline Mango waste & $51.7 \mathrm{bC}$ & $67.3 \mathrm{bB}$ & $73.6 \mathrm{aA}$ & 64.2 \\
\hline Passion fruit waste & $21.4 \mathrm{~dB}$ & $32.8 \mathrm{cA}$ & $28.2 \mathrm{bA}$ & 27.5 \\
\hline Mean & 44.6 & 52.1 & 51.6 & $\mathrm{CV}^{1} 6.48$ \\
\hline
\end{tabular}

Means followed by the same lowercase letter in the column and uppercase letter in the row do not differ according to Tukey's test $(\mathrm{P}>0.05) ;{ }^{1} \mathrm{CV}$ : coefficient of variation of the additive $\mathrm{x}$ compaction interaction $(\%)$.

Regardless of density, the treatment containing passion fruit waste had the highest $\mathrm{CP}$ content of all the treatments, which can be explained by the higher CP content of the waste (Table 1).

The addition of passion fruit and banana waste to the elephant grass ensiling process led to $\mathrm{CP}$ levels above the minimum of $70 \mathrm{~g} \mathrm{~kg}^{-1} \mathrm{CP}$ in DM recommended for good rumen functioning (VAN SOEST, 1994). The addition of mango waste in the elephant grass ensiling process did not quite reach the minimum recommended value for a density of $400 \mathrm{~kg} \mathrm{GM} \mathrm{m}^{-3}$, and the control treatment did not reach the minimum value at any density. When working with exclusively elephant grass silage, the use of an external protein source is recommended.

The additive $\mathrm{x}$ density interaction had a significant effect $(\mathrm{P}<0.05)$ on the EE parameter (Table 7). The EE content of the silage rose with the addition of the by-products, the only exception being the silage with passion fruit waste, which was expected due to the low EE concentration present in the waste (Table 1). The silage containing banana waste should be used with caution, preferably combined with some other feed, because silage from these additives has an EE content above the 60 to 70 $\mathrm{g} \mathrm{kg}^{-1} \mathrm{DM}$ limit, which may interfere with ruminal fermentation, compromise DM consumption, and reduce fiber digestibility (NRC, 2001).

The NDIN and ADIN parameters were influenced by the additive $\mathrm{x}$ density interaction ( $\mathrm{P}$ $<0.05$ ) (Table 8).

Regardless of density, the silage containing banana waste had the highest NDIN content. The control and mango waste-added silages did not differ at the $400 \mathrm{~kg} \mathrm{GM} \mathrm{m}^{-3}$ compaction, differing only at the other compactions, where the control silage had a lower NDIN content. The treatment containing passion fruit waste had a lower NDIN content than the others, regardless of density.

The NDIN levels for treatments with banana and mango waste and the control silage can be explained by the NDIN levels of the waste and forage (Table 1). The tendency of silage NDIN to decrease as density increases may be related to the degradation of protein fraction B3. According to Amaral et al. (2007), the higher the density is, the lower the B3 fraction concentrations in the silage. The increase in density did not influence NDIN content for the treatment with passion fruit waste. 
Table 8. Mean neutral detergent insoluble nitrogen as a percentage of total nitrogen (NDIN) and acid detergent insoluble nitrogen as a percentage of total nitrogen (ADIN) values for the additive $\mathrm{x}$ density interaction of elephant grass silage treated whith banana, mango and passion fruit waste.

\begin{tabular}{lcccc}
\hline \multirow{2}{*}{ Additive } & \multicolumn{3}{c}{ Density kg GM m${ }^{-3}$} & \multirow{2}{*}{ Mean } \\
\cline { 2 - 4 } & \multicolumn{3}{c}{ NDIN $\left(\mathrm{g} \mathrm{kg}^{-1} \mathrm{~N}\right.$-total $)$} \\
\hline Control & $149.7 \mathrm{bA}$ & $107.5 \mathrm{cB}$ & $105.9 \mathrm{cB}$ & 121.0 \\
Banana waste & $340.4 \mathrm{aA}$ & $320.0 \mathrm{aB}$ & $300.1 \mathrm{aC}$ & 320.1 \\
Mango waste & $161.6 \mathrm{bA}$ & $128.4 \mathrm{bB}$ & $125.1 \mathrm{bB}$ & 138.4 \\
Passion fruit waste & $73.6 \mathrm{c}$ & $71.4 \mathrm{~d}$ & $62.8 \mathrm{~d}$ & 69.3 \\
\hline Mean & 181.3 & 156.8 & 148.5 & $\mathrm{CV}^{1} 4.55$ \\
\hline \multicolumn{4}{c}{$\mathrm{ADIN}\left(\mathrm{g} \mathrm{kg}^{-1} \mathrm{~N}-\right.$-total $)$} \\
Control & $74.8 \mathrm{bA}$ & $41.6 \mathrm{bB}$ & $30.2 \mathrm{cC}$ & 48.9 \\
Banana waste & $204.4 \mathrm{aA}$ & $176.0 \mathrm{aC}$ & $185.1 \mathrm{aB}$ & 188.5 \\
Mango waste & $35.9 \mathrm{cA}$ & $29.0 \mathrm{cB}$ & $27.2 \mathrm{bcB}$ & 30.7 \\
Passion fruit waste & $20.8 \mathrm{~d}$ & $20.2 \mathrm{~d}$ & $21.4 \mathrm{~b}$ & 20.8 \\
\hline Mean & 84.0 & 66.7 & 66.0 & $\mathrm{CV}^{1} 6.48$ \\
\hline
\end{tabular}

Means followed by the same lowercase letter in the column and uppercase letter in the row do not differ according to Tukey's test $(\mathrm{P}>0.05) ;{ }^{1} \mathrm{CV}$ : coefficient of variation of the additive $\mathrm{x}$ compaction interaction (\%).

With regard to the density for each additive relative to the ADIN levels, the treatments behaved similarly for the different compactions. The treatment containing banana waste had the highest ADIN content, independent of density, followed by the control silage, silage with added mango waste, and silage with added passion fruit waste (Table 8). At a compaction of $600 \mathrm{~kg} \mathrm{GM} \mathrm{m}^{-3}$, there was a change where the control treatment did not differ from the silage containing mango waste. This result was expected because the exclusively grass silage exhibited good fermentation at $600 \mathrm{~kg} \mathrm{GM} \mathrm{m}^{-3}$ compaction and probably produced less heat at that particular density, reducing the content of nitrogen bound to the cell wall due to the Maillard reaction (AMARAL et al., 2007).

The ADIN content is related to the availability of protein, and higher ADIN content is associated with lower availability of protein because more nitrogen will be complexed to the ADF and unavailable to the animal. According to Coblentz and Hoffaman (2009), overheating of silage results in a reduction in protein digestibility due to the increase in ADIN content that becomes unavailable for ruminal microflora.
The effect of ensiling density was more noticeable for the exclusively elephant grass silage, where a compaction of $600 \mathrm{~kg} \mathrm{GM} \mathrm{m}^{-3}$ improved the fermentation and microbiological processes and decreased nutritional losses during fermentation.

The addition of banana, passion fruit, and mango by-products to elephant grass silage promotes an increase in silage DM, but the use of banana waste is not recommended because it does not favor fermentative and microbiological processes. The addition of the passion fruit and mango byproducts promoted increased DM and favored the fermentation, microbiological, and bromatological processes in the silage, regardless of density.

The use of fruit residues as additives to silage has been restricted to small dairy farms because the drying process and the addition of fruit residues to the silage that are performed manually. Studies on drying strategies and methods to incorporate additives to the silage process are needed in order to use that technique on medium and large properties. 


\section{Conclusion}

A compaction of $600 \mathrm{GM} \mathrm{m}^{-3}$ should be used for exclusively elephant grass silage.

The use of banana waste as an additive in elephant grass silage is not recommended.

Mango and passion fruit waste can be used as additives in elephant grass silage.

\section{Acknowledgments}

The authors thank PROPESP/UFPA and FADESP for financing the translation of the article.

\section{References}

AMARAL, C. A.; BERNARDES, T. F.; SIQUEIRA, G. R.; REIS, R. A. Características fermentativas e químicas de silagens de capim-marandu produzidas com quatro pressões de compactação. Revista Brasileira de Zootecnia, Viçosa, MG, v. 36, n. 3, p. 532-539, 2007.

ASSOCIATION OF OFFICIAL AGRICULTURAL CHEMISTS - AOAC. Official methods of analyses. $15^{\text {th }}$ ed. Virginia: Arlington, 1990. v. 1, 648 p.

ÁVILA, C. L. S.; PINTO, J. C.; FIGUEIREDO, H. C. P.; MORAIS, A. R.; PEREIRA, O. G.; SCHWAN, R. F. Estabilidade aeróbia de silagens de capim-mombaça tratadas com Lactobacillus buchneri. Revista Brasileira de Zootecnia, Viçosa, MG, v. 38, n. 5, p. 779-787, 2009.

ÁVILA, C. L. S.; PINTO, J. C.; SUGAWARA, M. S.; SILVA, M. S.; SCHWAN, R. F. Qualidade da silagem de cana-de-açúcar inoculada com uma cepa de Lactobacillus buchneri. Acta Scientiarum Animal Sciences, Maringá, v. 30, n. 3, p. 255-261, 2008.

CÂNDIDO, M. J. D.; NEIVA, J. N. M.; RODRIGUEZ, N. M.; FERREIRA, A. C. H. Características fermentativas e composição química de silagens de capim-elefante contendo subproduto desidratado do maracujá. Revista Brasileira de Zootecnia, Viçosa, MG, v. 36, p. 14891494, 2007. Suplemento.

CARVALHO, S.; RODRIGUES, M. T.; BRANCO, R. H.; RODRIGUES, C. A. F. Consumo de nutrientes, produção e composição do leite de cabras da raça Alpina alimentadas com dietas contendo diferentes teores de fibra. Revista Brasileira de Zootecnia, Viçosa, MG, v. 35, n. 3, p. 1154-1161, 2006. Suplemento.
CHAVES, K. F.; SILVA, N. B. N.; VIEIRA, T. B. V.; CRUZ, W. F.; MARTINS, M. L.; MARTINS, A. D. O. Avaliação microbiológica de ambientes de diferentes latcínios da região de rio pomba-MG. Revista do Instituto de Latícinios Cândido Tostes, Juiz de Fora, MG, v. 66, n. 380, p. 11-15, 2011.

CHERNEY, J. H.; CHERNEY, D. J. R. Assering silage quality. In: BUXTON, D. R.; MUCK. R. E.; HARRISON, J. H. (Ed.). Silage science and technology. Madison: American Society of Agronomy, Crop Science Society of America, Soil Science of America, 2003. p. 141-198.

COBLENTZ, W. K.; HOFFMAN, P. C. Effects of bale moisture and bale diameter on spontaneous heating, dry matter recovery, in vitro true digestibility, and in situ disappearance kinetics of alfalfa-orchardgrass hays. Journal of Dairy Science, Champaign, v. 92, n. 6, p. 2853-2874, 2009.

CRUZ, B. C. C.; SANTOS-CRUZ, C. L.; PIRES, A. J. V.; ROCHA, J. B.; SUELY, S.; BASTOS, M. P. V. Composição bromatológica da silagem de capim-elefante com diferentes proporções de casca desidratada de maracujá (Passiflora edulis Sims f. flavicarpa). Revista Brasileira de Ciências Agrárias, Recife, v. 5, n. 3, p. 434440, 2010.

FERREIRA, A. C. H.; NEIVA, J. N. M.; RODRIGUES, N. M.; CAMPOS, W. E. C.; BORGES, I. Avaliação nutricional do subproduto da agroindústria de abacaxi como aditivo de silagem de capim-elefante. Revista Brasileira de Zootecnia, Viçosa, MG, v. 38, n. 2, p. 223229, 2009.

INSTITUTO BRASILEIRO DE GEOGRAFIA E ESTATÍSTICA - IBGE. Levantamento sistemático da produção agrícola. Rio de Janeiro: IBGE, 2013. Disponível em: <http://www.sidra.ibge.gov.br $>$. Acesso em: 18 out. 2015.

JOBIM, C. C.; NUSSIO, L. G.; REIS, R. A.; SCHMIDT, P. Avanços metodológicos na avaliação da qualidade da forragem conservada. Revista Brasileira de Zootecnia, Viçosa, MG, v. 36, p. 101-119, 2007. Suplemento.

LACERDA, M. J. R.; FREITA, K. R.; SILVA, J. W. Determinação da matéria seca de forrageiras pelos métodos de microondas e convencional. Bioscience Journal, Uberlândia, v. 25, p.185-190, 2009.

LICITRA, G.; HERNANDEZ, T. M.; VAN SOEST, P. J. Standardization of procedures for nitrogen fractionation of ruminant feeds. Animal Feed Science and Technology, Amsterdam, v. 57, n. 4, p. 347-358, 1996. 
LOUSADA JÚNIOR, J. E.; COSTA, J. M. C.; NEIVA, J. N. M.; RODRIGUEZ, N. M. Caracterização físicoquímica de subprodutos obtidos do processamento de frutas tropicais visando seu aproveitamento na alimentação animal. Revista Ciência Agronômica, Fortaleza, v. 37, n. 1, p. 70-76, 2006.

MCDONALD, P.; HENDERSON, A. R.; HERON, S. J. E. Biochemistry of silage. $2^{\text {th }}$ ed. Marlow: Chalcombe Publication, 1991. $340 \mathrm{p}$.

MUCK, R. E. Silage microbiology and its control through additives. Revista Brasileira de Zootecnia, Viçosa, MG, v. 39, p. 183-191, 2010. Suplemento Especial.

NATIONAL RESEARCH COUNCIL - NRC. Nutrient requirements of dairy catlle. $7^{\text {th }}$ ed. Washington: National Academic Press, 2001. 381 p.

NUNES, H.; ZANINE, A. M.; MACHADO, T. M. M.; CARVALHO, F. C. Alimentos alternativos na dieta de ovinos. Archivos Latinoamericanos de Producción Animal, Viçosa, MG, v. 15, n. 4, p. 141-151, 2007.

OLIVEIRA, V. S.; MORAIS, J. A. S.; FAGUNDES, J. L.; SANTANA, J. C. S.; LIMA, I. G. S.; SANTOS, C. B. Produção e composição químico-bromatológica de gramíneas tropicais submetidas a dois níveis de irrigação. Archives of Veterinary Science, Curitiba, v. 20, n. 2, p. 27-36, 2015.

R DEVELOPMENT CORE TEAM - R: a language and environment for statistical computing. Vienna: $\mathrm{R}$ Foundation for Statistical Computing, 2006.

RIBEIRO, L. S. O.; PIRES, A. J. V.; CARVALHO, G. G. P.; PEREIRA, M. L. A.; SANTOS, A. B.; ROCHA, L. C. Características fermentativas, composição química e fracionamento de carboidratos e proteínas de silagem de capim-elefante emurchecido ou com adição de torta de mamona. Semina: Ciências Agrárias, Londrina, v. 35, n. 3, p. 1447-1462, 2014.

SÁ, C. R. L.; NEIVA, J. N. M.; GONÇALVES, J. S.; CAVALCANTE, M. A. B.; LÔBO, R. N. B. Composição bromatológica e características fermentativas de silagens de capim elefante (Pennisetum purpureum Schum.) com níveis crescentes de adição do subproduto da Manga (Mangifera indica L.). Revista Ciência Agronômica, Fortaleza, v. 38, n. 2, p. 199-203, 2007.

SANTOS, E. M.; ZANINE, A. M. Silagem de gramíneas tropicais. Colloquium Agrariae, Presidente Prudente, v. 2, n. 1, p. 32-45, 2006.

SANTOS, M. V. F.; GÓMES, C. A. G.; PEREA, J. M.; GARCIA, A.; GUIM, A.; PÉREZ, H. M. Fatores que afetam o valor nutritivo de silagens de forrageiras tropicais. Archivos de Zootecnia, Curitiba, v. 59, n. 1, p. 25-43, 2010.

SNIFFEN, C. J.; O'CONNOR, J. D.; VAN SOEST, P. J.; FOX, D. G.; RUSSEL, J. B. A net carbohydrate and protein system for evaluating cattle diets: II. Carbohydrate and protein availability. Journal of Animal Science, Champaign, v. 70, n. 11, p. 3562-3577, 1992.

VAN SOEST, P. J. Nutritional ecology of the ruminant. $2^{\text {th }}$ ed. Ithaca: Cornell University Press, 1994. 463 p.

VAN SOEST, P. J.; ROBERTSON, J. B.; LEWIS, B. A. Methods for dietary fiber, neutral detergent fiber, and nonstarch polysaccharides in relation to animal nutrition. Journal of Dairy Science, Ithaca, v. 74, n. 10, p. 35833597, 1991. 
